\title{
PENERAPAN STRATEGI MEANINGFUL LEARNING DALAM MENINGKATKAN HASIL BELAJAR MAHASISWA PENDIDIKAN MATEMATIKA UMSURABAYA PADA MATA KULIAH PENGANTAR PENDIDIKAN
}

\author{
Shoffan Shoffa \\ Program Studi Pendidikan Matematika, FKIP UMSurabaya \\ shoffanshoffa@gmail.com
}

\begin{abstract}
ABSTRAK
Salah satu faktor yang seringkali dijadikan tolak ukur keberhasilan pendidikan adalah dengan melihat keberhasilan proses belajar-mengajar dalam mencapai tujuannya. Faktor lain yang sangat berperan saat ini adalah motivasi seorang peserta didik dalam rangka mempersiapkan dirinya untuk memulai sebuah proses belajar mengajar. Dalam usaha pencapaian tujuan pendidikan yang diinginkan tentunya banyak sekali metode-metode pembelajaran yang diterapkan pada kancah lingkungan pendidikan terutama bagi pendidikan yang bertujuan untuk meningkatkan motivasi seorang peserta didik Proses pengajaran pengantang pendidikan sering menggunakan metode ceramah, mahasiswa kurang aktif. Hal ini menyebabkan hasil belajar siswa tidak tercapai secara optimal. Penelitian ini bertujuan untuk meningkatkan hasil belajar mahasiswa dengan menerapkan strategi meaningful learning dengan jenis penelitian tindakan kelas dengan dua siklus. Tiap siklus terdiri atas tahapan perencanaan, tindakan, observasi dan refleksi. Pengambilan data dilakukan dengan tes, observasi, dan angket. Analisis data dilakukan dengan analisis statistik deskriptif. Berdasarkan analisis data penelitian, ketuntasan belajar mahasiswa meningkat, pada siklus I yaitu $60,98 \%$ dan siklus II meningkat menjadi $78,05 \%$. Keaktifan dosen 67,97\% pada siklus I dan $80,47 \%$ pada siklus II. Keaktifan siswa siklus I yaitu 51,22\% dan siklus II yaitu $75,61 \%$. Respon mahasiswa 75,61\% yang menyatakan setuju dalam angket. Dari hasil tersebut, penelitian ini mencapai indikator keberhasilan dan dapat disimpulkan bahwa strategi meaningful learning dapat dilakukan dan diterima mahasiswa dalam pembelajaran mata kuliah pengantar pendidikan.
\end{abstract}

Kata kunci: hasil belajar; meaningful learning; strategi belajar.

\section{PENDAHULUAN}

Salah satu faktor yang seringkali dijadikan tolak ukur keberhasilan pendidikan adalah dengan melihat keberhasilan proses belajar-mengajar dalam mencapai tujuannya. Faktor lain yang sangat berperan saat ini adalah motivasi seorang peserta didik dalam rangka mempersiapkan dirinya untuk memulai sebuah proses belajar mengajar. Dalam usaha pencapaian tujuan pendidikan yang diinginkan tentunya banyak sekali metode-metode pembelajaran yang diterapkan pada kancah lingkungan pendidikan terutama bagi pendidikan yang bertujuan untuk meningkatkan motivasi seorang peserta didik. Salah satu langkah untuk memiliki strategi itu dengan cara guru harus menguasai teknik-teknik pengajaran atau metode mengajar (Roestiyah NK,1991:1). 


\section{Shoffan Shoffa}

Namun tidak semua metode mengajar yang digunakan itu selalu berdampak positif terhadap pola pembelajaran peserta didik yang kita hadapi karena seperti kita ketahui bahwa setiap peserta didik itu mempunyai karakteristik yang berbeda antara satu dengan yang lainnya. Dalam menentukan metode yang nanti akan kita gunakan hendaknya harus sesuai juga dengan materi yang kita ajarkan karena hal tersebut akan sangat berpengaruh terhadap motivasi belajar seorang peserta didik. Seperti halnya yang diungkap oleh Sutama (2000) tentang peningkatan efektifitas belajar melalui gaya mengajar menyimpulkan bahwa dalam penyampaian materi pelajaran, seorang guru harus bisa menentukan metode apa yang tepat sesuai dengan materi yang akan disampaikan sehingga prestasi belajar siswa akan tercapai sesuai tujuan.

Dengan demikian peran seorang pendidik dalam mengembangan pola pikir peserta didiknya menjadi sorotan utama dalam rangka menuju wadah moral pendidikan yang diidamkan oleh kita semua. Untuk itu kita sebagai pendidik penting menekankan penggunaan metode pengajaran yang tepat sesuai dengan minat serta bakat peserta didik atau pada mahasiswa yang mereka nantinya akan menjadi calon-calon pendidik setelah selesai di bangku perkuliahan. Maka secara operasional permasalahan yang akan diteliti oleh penulis dapat dirumuskan sebagai berikut: (1) Beberapa besar pengaruh motivasi terhadap minat belajar seorang peserta didik? (2) Metode apakah yang paling baik digunakan dalam strategi peningkatan motivasi belajar mahasiswa dalam mata kuliah Pengantar Pendidikan di Prodi Pendidikan Matematika UMSurabaya?

Penyusunan karya tulis berjudul "Strategi Peingkatan Motivasi Mahasiswa dalam Mata kuliah pengantar pendidikan" ini diharapkan mampu memberikan perkembangan pola atau metode pembelajaran yang dapat meningkatkan motivasi belajar mahasiswa sehingga melahirkan generasi muda yang lebih unggul di masa akan datang. Adapun gambaran secara umu tujuan karya ilmiah ini adalah: (1) Untuk mengetahui seberapa besarnya pengaruh motivasi terhadap minat belajar seorang peserta didik. (2)Mengetahui metode yang paling baik digunakan dalam strategi peningkatan motivasi belajar mahasiswa dalam mata kuliah pengantar pendidikan di kalangan mahasiswa Matematika UMSurabaya. 


\section{METODE PENELITIAN}

Penelitian ini merupakan Penelitian Tindakan Kelas (PTK). Hal ini disebabkan karena penelitian ini berorientasi pada penerapan tindakan dengan tujuan peningkatan mutu atau pemecahan masalah pada sekelompok subjek yang diteliti dan mengamati tingkat keberhasilan atau akibat tindakannya, untuk kemudian diberikan tindakan lanjutan yang bersifat penyempurnaan tindakan atau penyesuaian dengan kondisi dan situasi sehingga diperoleh hasil yang lebih baik. Penelitian ini dilakukan selama pelaksanaan tindakan dalam dua siklus. Tahapan dalam pelaksanaan PTK menurut Trianto (2012: 35) yaitu: penyusunan rencana (planning), melakukan tindakan (acting, pengamatan (observating, dan refleksi (reflecting). Penelitian ini pada mahasiswa pendidikan matematika angkatan 2015, Fakuktas Keguruan dan Ilmu Pendidikan, Universitas Muhammadiyah Surabaya.

Metode pengumpulan data yang digunakan adalah metode observasi, metode tes dan metode angket. Metode observasi digunakan untuk mengumpulkan data tentang aktifitas dosen dan aktifitas siswa di kelas selama proses pembelajaran dengan menerapkan strategi meaningful learning. Metode tes digunakan untuk mendapatkan data tentang hasil belajar siswa setelah melakukan pembelajaran dengan menerapkan strategi meaningful learning, tes dilaksanakan di akhir pembelajaran setiap siklus, soal tes dibuat dalam bentuk soal uraian yang terdiri dari 5 butir soal. Sedangkan metode angket digunakan untuk mendeskripsikan respon siswa setelah melakukan pembelajaran dengan menerapkan strategi meaningful learning. Angket diberikan kepada siswa pada akhir pembelajaran di akhir siklus.

\section{HASIL PENELITIAN DAN PEMBAHASAN}

Hasil penelitian ini meliputi hasil belajar siswa, aktifitas siswa dan angket Respon siswa pada siklus I dan II. Hasil belajar siswa ditunjukkan dalam tabel berikut ini:

Tabel 1: Hasil Belajar mahasiswa Pada Siklus I dan Siklus II

\begin{tabular}{|c|c|c|c|}
\hline Hasil Belajar mahasiswa & Nilai Tes Sebelum PTK & Siklus I & Siklus II \\
\hline Tuntas Belajar & 16 & 20 & 27 \\
\hline Tidak Tuntas Belajar & 15 & 11 & 4 \\
\hline Nilai Rata-rata & 70,85 & 73,05 & 77,12 \\
\hline Persentase Ketuntasan Belajar & $51,22 \%$ & $60,98 \%$ & $78,05 \%$ \\
\hline
\end{tabular}


Berdasarkan tabel 1 diketahui bahwa hasil belajar siswa mengalami peningkatan dari sebelum dikenai tindakan dan setelah dikenai tindakan dengan menerapkan strategi meaningful learning. Hasil evaluasi siklus I dengan nilai ratarata siswa mencapai 73,05 dengan ketuntasan belajar 60,98\% sebanyak 20 mahasiswa sedangkan yang belum tuntas belajar sebanyak 11 siswa. Pada siklus II mengalami peningkatan dengan nilai rata-rata siswa mencapai 77,12 dengan ketuntasan belajar 78,05\% sebanyak 27 mahasiswa sedangkan yang belum tuntas belajar sebanyak 4 mahassiswa. Dengan demikian melalui penerapan strategi meaningful learning dapat meningkatkan hasil belajar mahasiswa pada matakuliah pengantar pendidikan

Tabel 2: Analisis Hasil Aktifitas Dosen Pada Siklus I dan Siklus II

\begin{tabular}{|c|c|c|c|c|c|c|}
\hline \multirow{2}{*}{ Siklus } & \multicolumn{2}{|c|}{$\begin{array}{c}\text { Jumlah Skor } \\
\text { Pertemuan ke- }\end{array}$} & \multicolumn{2}{c|}{$\begin{array}{c}\text { Persentase } \\
\text { Pertemuan ke- }\end{array}$} & \multirow{2}{*}{$\begin{array}{c}\text { Rata-rata } \\
\text { Skor }\end{array}$} & $\begin{array}{c}\text { Rata-rata } \\
\text { Persentase }\end{array}$ \\
\cline { 2 - 5 } & $\mathbf{1}$ & $\mathbf{2}$ & $\mathbf{1}$ & $\mathbf{2}$ & & \\
\hline Siklus I & 42 & 45 & $65,63 \%$ & $70,31 \%$ & 43,5 & $67,97 \%$ \\
\hline Siklus II & 49 & 54 & $76,56 \%$ & $84,38 \%$ & 51,5 & $80,47 \%$ \\
\hline
\end{tabular}

Berdasarkan tabel 2 terdapat peningkatan rata-rata persentase aktifitas dosen, terlihat siklus I ke siklus II terdapat peningkatan rata-rata persentase aktifitas dosen dalam kategori aktif sebesar 12,5\%. Berdasarkan kriteria penilaian aktifitas dosen, pada siklus I rata-rata skor yang diperoleh dari lembar observasi aktifitas dosen yaitu 43,5 dari skor maksimal 64 dengan rata-rata persentase sebesar $70,31 \%$. Sedangkan pada siklus II rata-rata skor yang diperoleh dari lembar observasi aktifitas guru yaitu 51,5 dari skor maksimal 64 dengan rata-rata persentase sebesar $80,47 \%$.

Berdasarkan hasil observasi bahwa dosen sudah lebih memperhatikan siswa pada saat siswa mengalami kesulitan serta penguasaan kelas dalam proses pembelajaran berlangsung dengan baik. Dosen juga dapat lebih trampil dalam memberi umpan balik kepada siswa dalam menarik kesimpulan dengan benar. 
Tabel 3: Analisis Hasil Aktifitas Belajar Mahasiswa

\begin{tabular}{|l|c|c|c|c|c|c|}
\hline \multicolumn{1}{|c|}{ Aktivitas } & $\begin{array}{c}\text { Persentase } \\
\text { Pertemuan } \\
\text { Ke-1 }\end{array}$ & $\begin{array}{c}\text { Persentase } \\
\text { Pertemuan } \\
\text { Ke-2 }\end{array}$ & $\begin{array}{c}\text { Rata- } \\
\text { rata }\end{array}$ & $\begin{array}{c}\text { Persentase } \\
\text { Pertemuan } \\
\text { Ke-4 }\end{array}$ & $\begin{array}{c}\text { Persentase } \\
\text { Pertemuan } \\
\text { Ke-5 }\end{array}$ & $\begin{array}{c}\text { Rata- } \\
\text { rata }\end{array}$ \\
\hline Aktif $(\geq 75 \%)$ & $46,34 \%$ & $56,10 \%$ & $51,22 \%$ & $70,73 \%$ & $80,49 \%$ & $75,61 \%$ \\
\hline $\begin{array}{l}\text { Cukup Aktif } \\
(51 \%-74 \%)\end{array}$ & $12,20 \%$ & $43,90 \%$ & $28,05 \%$ & $29,27 \%$ & $19,51 \%$ & $24,39 \%$ \\
\hline $\begin{array}{l}\text { Kurang Aktif } \\
(\leq 26 \%-50 \%)\end{array}$ & $41,46 \%$ & $0 \%$ & $20,73 \%$ & $0 \%$ & $0 \%$ & $0 \%$ \\
\hline $\begin{array}{l}\text { Tidak Aktif }(0 \% \\
-25 \%)\end{array}$ & $0 \%$ & $0 \%$ & $0 \%$ & $0 \%$ & $0 \%$ & $0 \%$ \\
\hline Jumlah & $\mathbf{1 0 0 \%}$ & $\mathbf{1 0 0 \%}$ & $\mathbf{1 0 0 \%}$ & $\mathbf{1 0 0} \%$ & $\mathbf{1 0 0 \%}$ & $\mathbf{1 0 0 \%}$ \\
\hline
\end{tabular}

Berdasarkan tabel 3 terdapat peningkatan rata-rata persentase aktifitas belajar mahasiswa prodi pendidikan matematika, dari siklus I ke siklus II terdapat peningkatan rata-rata persentase aktifitas siswa dalam kategori aktif sebesar 12,4\%. Rata-rata persentase aktifitas siswa dalam kategori cukup aktif mengalami penurunan sebesar 3,66\%. Berdasarkan hasil observasi bahwa siswa sudah lebih memperhatikan guru dalam menjelaskan materi. Dalam bekerjasama dengan kelompok juga meningkat, serta dalam menyelesaikan soal siswa mampu menyelesaikan dengan baik. Siswa juga dapat lebih trampil dalam berdiskusi, serta siswa dapat menarik kesimpulan dengan benar.

Tabel 4: Analisis Hasil Angket Respon mahasiswa

\begin{tabular}{|c|c|c|}
\hline \multicolumn{3}{|c|}{ Respon mahasiswa } \\
\hline Respon & Jumlah Siswa & Persentase \\
\hline Sangat Setuju (91\%-100\%) & 0 & $0 \%$ \\
\hline Setuju (61\% - 90\%) & 31 & $75,61 \%$ \\
\hline KurangSetuju (31\%-60\%) & 10 & $24,39 \%$ \\
\hline Tidak Setuju (0\% - 30\%) & 0 & $0 \%$ \\
\hline Jumlah & 41 & $100 \%$ \\
\hline
\end{tabular}

Berdasarkan tabel 4 di atas, respon siswa yang muncul hanya menunjukkan setuju dan kurang setuju. Respon yang menyatakan setuju sebanyak 31 siswa atau 75,61\% dari jumlah siswa dan yang kurang setuju sebanyak 10 siswa atau 24,39\% dari jumlah siswa. Dengan demikian siswa menunjukkan respon positif atau respon setuju terhadap strategi meaningful learning dalam pembelajaran matematika. 


\section{Shoffan Shoffa}

\section{SIMPULAN}

Berdasarkan hasil penelitian dan pembahasan yang telah diuraikan, dapat disimpulkan sebagai berikut:

1. Strategi pembelajaran yang diterapkan peneliti, yaitu penerapan strategi meaningful learning dalam pembelajaran matematika dapat meningkatkan hasil belajar siswa kelas VII MTs. Al Amin Krian pada materi bangun datar segiempat. Peningkatan ini terlihat dari nilai rata-rata yang diperoleh siswa yaitu ketuntasan belajar sebelum PTK, terdapat 16 mahasiswa mencapa ketuntasan belajar atau 51,22\% dari jumlah siswa, siklus 1 terdapat 20 mahasiswa mencapai ketuntasan belajar atau $60,98 \%$ dari jumlah siswa, dan siklus 2 terdapat 27 siswa mencapai ketuntasan belajar atau 78,05\% dari jumlah siswa. Dengan demikian ketuntasan belajar mahasiswa mencapai indikator keberhasilan yaitu $\geq 75 \%$ mahasiswa memperoleh ketuntasan

2. Aktivitas kemampuan dosen alam mengelola pembelajaran meningkat disetiap pertemuan. Pada pertemuan ke-1 memperoleh nilai total 42 atau $65,63 \%$ dari total skor maksimal indikator, pertemuan ke-2 memperoleh nilai total 45 atau $70,31 \%$ dari total skor maksimal indikator. Jadi, rata-rata persentase pada siklus 1 yaitu 67,97\%. Pertemuan ke-4 memperoleh nilai total 49 atau $76,56 \%$ dari total skor maksimal indikator, pertemuan ke-5 memperoleh nilai total 54 atau 84,38\% dari total skor maksimal indikator. Jadi, rata-rata persentase pada siklus 2 yaitu 80,47\%. Rata-rata persentase tersebut mencapai indikator keberhasilan dimana mencapai $75 \%$ kategori aktif atau baik.

3. Aktivitas belajar mahasiswa meningkat disetiap pertemuan. Pada siklus 1 pertemuan ke-1 siswa dalam kategori aktif sebanyak 14 mahasiswa atau $46,34 \%$ dari jumlah siswa, pertemuan ke-2 aktivitas mahasiswa dalam kategori aktif sebanyak 18 mahasiswa atau 56,10\% dari jumlah mahasiswa. Jadi, rata-rata persentase aktivitas mahasiswa dalam kategori aktif pada siklus 1 yaitu 51,22\%. Pada siklus 2 pertemuan ke-4 siswa dalam kategori aktif sebanyak 24 mahasiswa atau 70,73\% dari jumlah siswa, pertemuan ke-5 aktivitas mahasiswa dalam kategori aktif sebanyak 29 mahasiswa atau 80,49\% 
dari jumlah mahasiswa. Jadi, rata-rata persentase aktivitas siswa dalam kategori aktif pada siklus 2 yaitu 75,61\%. Dengan demikian aktivitas maha siswa mencapai indikator keberhasilan dengan kriteria aktif.

4. Respon mahasiswa pendidikan matematika, FKIP UMSurabaya $75,61 \%$ yang menyatakan setuju dalam angket, hal ini menunjukkan bahwa penerapan strategi meaningful learnig dalam pembelajaran matakuliah Pengantar Pendidikan.

\section{DAFTAR PUSTAKA}

Cahyo, Agus N. 2013. Panduan Aplikasi Teori-Teori Belajar Mengajar Teraktual dan Terpopuler. Yogyakarta: DIVA Press.

Dahar, Ratna Wilis. 2011. Teori-Teori Belajar dan Pembelajaran. Jakarta: Erlangga.

Ngalimun. 2012. Strategi dan Model Pembelajaran. Yogyakarta: Aswaja Pressindo.

Purwanto. 2013. Evaluasi Hasil Belajar. Yogyakarta: Pustaka Pelajar.

Roestiyah.1991. Strategi Belajar Mengajar. Cetakan IV.Jakarta : Rineka Cipta.

Suprijono, Agus. 2010. Cooperative Learning. Yogyakarta: Pustaka Pelajar Sutama.2000.Peningkatan efektifitas Pemnelajaran Matematika melalui Pembenahan Gaya Mengajar Guru di SMP Negeri 18 Surakarta.Tesis (tidak diterbitkan).Yogyakarta: Pasca Sarjana UNY.

Trianto. 2012. Panduan Lengkap Penelitian Tindakan Kelas (Classroom Action Research) Teori dan Praktek. Jakarta: Prestasi Pustakaraya. 